\title{
Agenda Control in the Bundestag, 1980-2002
}

\section{WILLIAM M. CHANDLER, GARY W. COX and MATHEW D. MCCUBBIN}

\begin{abstract}
We find strong evidence of monopoly legislative agenda control by government parties in the Bundestag. First, the government parties have near-zero roll rates, while the opposition parties are often rolled over half the time. Second, only opposition parties' (and not government parties') roll rates increase with the distances of each party from the floor median. Third, almost all policy moves are towards the government coalition (the only exceptions occur during periods of divided government). Fourth, roll rates for government parties skyrocket when they fall into the opposition and roll rates for opposition parties plummet when they enter government, while policy movements go from being nearly 100 per cent rightward when there is a rightist government to 100 per cent leftward under a leftist government.
\end{abstract}

\section{INTRODUCTION}

Governing coalitions in parliamentary democracies are famous for their voting cohesion. Individual MPs rarely dissent from their party's position, coalition partners rarely disagree publicly, and the government's programme thus proceeds through the assembly on the strength of the coalition's numerical superiority - simply outvoting the opposition at every turn.

Iron discipline, however, is not a natural phenomenon. The component parties in multiparty coalitions do not agree on all possible issues; they merely agree on all issues actually considered in plenary sessions of the assembly. ${ }^{1}$ Thus, the high levels of coalition discipline observed in roll call votes are as much a function of governmental agenda control - specifically, the ability of the coalition to prevent bills that would split its members apart from being voted on the floor - as they are of the carrots and sticks that governing parties use to whip their members into line. ${ }^{2}$

In some polities, such as France's Fifth Republic, ${ }^{3}$ the government's ability to control the legislative agenda has clear institutional sources. In this article, we explore agenda setting in Germany, a case in which the government's institutional control of the agenda might be questioned - given the tradition of seeking broad consensus in the Council of Elders (the formal agenda-setting institution in the Bundestag) and the frequency with which the government does not command a majority in the second chamber (the Bundesrat). We argue that the Council of Elders seeks - and is expected by the opposition to seek - only a procedural and not a substantive consensus; that the government is relatively successful at patching together support in the Bundesrat; and thus, that the most likely impediments to governmental agenda 
control in Germany are not serious in practice. We then show that the actual plenary agenda in Germany is consistent with the notion that the governing coalition sets the agenda, with little more constraint than is observed in other parliamentary cases.

\section{AGENDA CONTROL AND LEGISLATIVE PROCEDURE IN THE BUNDESTAG ${ }^{4}$}

The Bundestag allocates committee chairs and other important offices proportionally among all parties, without giving the governing coalition a bonus, as is common in many other systems. Moreover, as already noted, the Council of Elders seeks, and usually achieves, a consensus among all (or nearly all) parties regarding the plenary agenda. ${ }^{5}$ It is rare that parties seek to add items to the plenary agenda and such attempts almost always fail. ${ }^{6}$

Does the apparent consensus achieved in the Council of Elders mean the government must avoid bills the opposition dislikes? Does it imply a kind of universalism in which shifting coalitions take turns pushing bills onto the plenary agenda? In practice, as we shall see, it means neither of these things. The German government appears willing and able to push through legislation that is fiercely opposed by the opposition. Moreover, the only important bills that make it onto the plenary agenda are those supported, not by shifting majority coalitions, but by one particular majority coalition that composed of the governing parties.

How do governmental parties achieve agenda control given proportional allocation of committee chairs and 'consensual' agenda formation?' The answer is that governmental parties control the agenda because:

(1) They hold a majority of seats in all the core working and leadership bodies of the chamber, mainly the committees and the Council of Elders.

(2) The Council of Elders does not aim for a consensus on the substance of the bills to be considered in the plenary session, but only on the details of how such bills should be debated and voted. The opposition parties accept that the majority should be allowed to control the substantive content of the bills that the government sends to the Bundestag. Their demands only concern their ability to criticise such proposals effectively.

(3) Challenges to the agenda set by the Council of Elders are decided by majority vote in the Bundestag. Thus, the government parties can implement any agreement they reach among themselves regarding what should and should not appear on the agenda, if their representatives on the Council of Elders act in accord with the coalition's agreement (and their rank and file is willing to vote down attempts to amend the government's agenda on the floor).

\section{Government Majorities}

Regarding the government's possession of a majority on all committees and in the Council of Elders, the number of members from each parliamentary group on a committee is proportional to the size of the parliamentary group (and each fraction has discretion over which of its members will sit on each committee). Thus, as long as governmental parties maintain a majority in the Bundestag (which has always been the case), they have a majority on each committee. 
Committee chairs are allocated proportionally among all parties, meaning that the government cannot always count on a sympathetic chair. The Bundestag can, however, compel a committee to report on any matters referred to it within ten weeks. ${ }^{8}$ Thus, chairs by themselves cannot block, although they may delay, the progress of legislation.

The Council of Elders manages the internal affairs of the Bundestag. Some of the most important agenda-setting functions of the Council are: deciding the agenda for the coming year, deciding the distribution of committee chairs and deputy chairs among fractions, ${ }^{9}$ and importantly deciding the plenary agenda for each coming week (the items of business to be considered, whether there will be a debate, and the length and structure of such a debate). The government has a majority in this leadership body, just as it has a majority on committees and all other bodies of the chamber. ${ }^{10}$

\section{The Meaning of Consensus}

Turning now to the second and third points made above, what of the long tradition of seeking consensus in the Council of Elders? ${ }^{11}$ Were this an ironclad rule, it might imply that only bills approved by all parties could reach the plenary agenda. Our reading of the matter is that difficulty in achieving substantive consensus on the merits of bills brought forward by the government in the early 1950s led the Council to issue an interpretation in 1955, allowing items to be added to the floor agenda by majority vote on the floor. ${ }^{12}$ This ruling, we believe, made it clear that the government could get its way, so long as it was internally united, even without a consensus in the Council of Elders. It, therefore, reduced the scope of bargaining within the Council. Opposition parties no longer sought to veto or delay government bills, but merely to ensure that they had a fair chance to criticise those bills. Consensus in the Council thus implies only procedural and not substantive agreement.

\section{Divided Government}

One final question is whether the government's ability to control the agenda is lessened when it does not command a majority in the second chamber. As Patzelt ${ }^{13}$ notes, 'governing without control of the Bundesrat is quite common for German Chancellors'. Moreover, many politicians and scholars in Germany believe that divided control of the bicameral German parliament is causing gridlock reminiscent of the kind found in the US. ${ }^{14,15}$

We shall show that divided government has a statistically discernible, yet small, effect on the government's ability to control the agenda and make policy. The effect is small because the government manages to secure the support of the Bundesrat even during divided government, by buying off the votes of Länder delegations to whom it allocates funds in exchange for their support.

\section{THE PROCEDURAL CARTEL THESIS}

\section{Agenda Cartels}

In all democratic national assemblies of which we are aware, there are certain offices to which special agenda powers attach. Only the speaker of the US House of 
Representatives, for example, can grant recognition for motions to suspend the rules. Only ministers of the Crown can propose new taxes in the UK. Only the German Council of Elders can advise the president regarding the plenary agenda.

We define an agenda cartel as a set of agents possessing two key properties. First, they collectively hold a controlling share of the agenda-setting offices in the assembly. Thus, just as an economic cartel collectively monopolises an economic resource, such as steel, so too does an agenda cartel collectively monopolise a legislative resource, agenda-setting offices. Second, the cartel establishes a procedure for scheduling proposals for plenary debate and vote. Whether decentralised or centralised, formal or informal, this procedure amounts to investing $\mathrm{k}$ groups within the cartel, labeled $\mathrm{C}_{1}, \ldots, \mathrm{C}_{\mathrm{k}}$, with vetoes over the placement of proposals upon the plenary agenda.

One subspecies of agenda cartel - which we call a parliamentary agenda cartel - is of particular concern here. In parliamentary systems, it is often said that each pivotal party in a multi-party majority coalition wields an agenda veto. ${ }^{16}$ In this case, the groups $\mathrm{C}_{1}, \ldots, \mathrm{C}_{\mathrm{k}}$ that wield agenda vetoes correspond to the pivotal parties in government. In Germany, there is strong evidence that coalition partners have important veto powers that are often formalised by written agreements between parties: '.. a formal coalition agreement... is signed prior to the Chancellor's election by the Bundestag. In the present coalition agreement it is stipulated that no decisions in the Bundestag shall be taken with 'changing majorities' - that is, those forged through the inclusion of votes from the opposition. This clause endows minority groups of both parties, and of course the junior coalition partner as a whole, with absolute veto power in intra-coalition policy making. ${ }^{17,18}$

\section{The Cartel Thesis}

The procedural cartel thesis stipulates that, if a majority government forms, then it will also constitute an agenda cartel. ${ }^{19}$ For present purposes, we advance this thesis simply as an empirical generalisation to be tested, rather than deriving it as a conclusion from more primitive assumptions. This thesis is thus similar to Gamson's Law - the observation that, if a multi-party government forms in a parliamentary system, then each party's share of portfolios will closely reflect its share of seats in the assembly. ${ }^{20}$

Both the claim that agenda vetoes are distributed to each pivotal party (the parliamentary cartel thesis) and the claim that portfolios in parliamentary systems are distributed proportionally to seat shares (Gamson's Law) characterise the government bargaining outcomes that emerge in equilibrium. Theoretical models of the government formation process should then accommodate these empirical regularities, to the extent that they are empirically validated. A primary purpose of this article is to see how well the procedural cartel thesis applies to the German case.

\section{TESTING THE PROCEDURAL CARTEL THESIS}

Many studies of the legislative success of parliamentary governments examine the proportion of bills introduced by the government that pass. ${ }^{21}$ Here, we examine roll rates, rather than success rates. Operationally, if a majority of a party's voting members votes against a bill that nonetheless passes, we say that the party has been rolled. Think of a legislative train leaving the station and a party that has tried to 
stop it - but has been run over. What one expects the roll rate of a governing party to be depends on how one thinks the legislative agenda is determined.

\section{The Floor Agenda Model}

Suppose there is no agenda cartel and the plenary agenda is set by motions made and voted on the floor, with all parties having equal chances to bring such motions. If we assume that all parties can be placed along a traditional left-right scale, then this Floor Agenda Model leads to a very simple expectation: the median party is never rolled, while roll rates increase monotonically both to the left and to the right of the median, regardless of government status.

The intuition behind this result is straightforward. The median party cannot be rolled because it is not possible to form a majority that wants to move policy away from the median in a unidimensional model. That roll rates increase to either side of the median, F, can be illustrated by imagining that a particular status quo policy, Q1, lies between two right-wing parties' ideal points and that a bill proposing to move policy leftward is passed (see Figure 1). ${ }^{22}$ The more extreme party (R2 in Figure 1) will necessarily vote against the bill, as the bill will move policy farther away from R2's ideal point; hence, it will be rolled. The more moderate party (R1 in Figure 1) may in fact vote for the bill, if it is closer to the party's ideal point, R1, than is the status quo. In this case (pictured in Figure 1), the moderate party is not rolled. Generalising this example, one can show that the roll rate of the more extreme party must be at least as high as that of the more moderate party - and this is true for parties and policies to the left of the median party (for example, for parties L1 and L2, and status quo, Q2) as well. 
Thus, we have a general test for the absence of an agenda cartel. If there is a clear $\mathrm{V}$-shaped pattern in party rolls, viewed across the left-right spectrum, then there cannot be an agenda cartel.

\section{The Cartel Agenda Model}

If there is an agenda cartel (meaning each pivotal government party wields a de facto veto), we should not see legislation reaching the floor that any governing party then unsuccessfully opposes. For, any pivotal governing party that anticipates being rolled on a particular bill should exercise its veto to prevent the bills appearance on the plenary agenda.

Consider, as an example, the uni-dimensional policy space in Figure 2. The government consists of two parties, with ideal points $\mathrm{M}$ and F. Party F is also the median party in the assembly as a whole. The point $\mathrm{m}$ is the ideal point of a party in the opposition.

The Cartel Agenda Model predicts that the government will only schedule for a vote those bills that ultimately (after any floor amendments) move policy closer to both $\mathrm{M}$ and $\mathrm{F}$. If the status quo is closer to $\mathrm{M}$ than is $\mathrm{F}-$ as is $\mathrm{SQ}_{1}$ in Figure $2-$ then no bill to change policy will be presented to the chamber by the government. This is because $M$ will anticipate that, if a bill changing a status quo policy like $\mathrm{SQ}_{1}$ is allowed onto the floor, then the bill will pass if and only if it moves policy toward $\mathrm{F}$ and away from M. Thus, as shown in Figure 2, all proposals to change status quo points lying in the set $[2 \mathrm{M}-\mathrm{F}, \mathrm{F}]$ will be blocked by the government (pursuant to demands made by M). ${ }^{23}$ Thus, we have the following hypothesis:

H1) Under complete information with costless gatekeeping, the roll rate of governmental parties will be zero. ${ }^{24}$ 
The opposition (or minority) party, by contrast, will be rolled - every time the status quo lies in the opposition roll zone, that is, the interval between $\mathrm{F}$ and $2 \mathrm{~m}-\mathrm{F}$. Thus, bills to change status quos such as $\mathrm{SQ}_{2}$ will be brought to the floor, will pass, and will thus roll party $\mathrm{m}$. This logic leads to the roll rates described in Figure 3 and to our second hypothesis:

H2) The roll rate of opposition parties should be higher than the roll rate of governmental parties.

Because the government will not allow any bill onto the agenda when $\mathrm{M}$ (the leftmost member of the governing coalition) prefers the status quo to $\mathrm{F}$ (the floor median), the distance between $M$ and $F$ should not affect the government's roll rate (decreases in M merely stretch the blockout zone leftward and the government will still block all proposals to change status quos within [2M-F, F]). In contrast, an opposition party's roll rate will be positively related to the distance between $\mathrm{m}$ and $\mathrm{F}$ (as $\mathrm{m}$ increases, $2 \mathrm{~m}-\mathrm{F}$ increases, stretching the minority party roll zone). Moreover, as an opposition party's distance from $\mathrm{F}$ (the position of the median voter) increases, so should its roll rate. Thus:

H3) The roll rate of an opposition party should increase the farther its median ideal point $(m)$ is from the floor median $(F)$. That is, the greater $|m-F|$, the greater an opposition party's roll rate, all else constant.

To see how agenda-setting power can affect legislative outcomes, imagine a newly elected legislature and the set of existing government policies (we could label each one $S Q_{1}, S Q_{2}, \ldots, S Q_{n}$ as in Figure 2) that it faces. Each of these policies could in principle 
be adjusted, sliding them further to the left or right (for example, less generous or more generous unemployment benefits). The newly elected members and their parties have opinions regarding how each of the $n$ policies ideally should be positioned along their respective left-right dimensions. Denote the centre of legislative opinion (the median ideal position) regarding each policy by $F_{1}, \ldots, F_{n}$ for the $n$ policies (one such policy is depicted in Figure 2).

One can divide existing government policies into two main categories, depending on the relationship between the legislative median $\left(F_{j}\right)$ and the status quo $\left(S Q_{j}\right)$. In one category are policies that lie to the left of the current centre of legislative opinion $\left(S Q_{j}<F_{j}\right)$. If the legislature votes to change such a policy from the status quo (for example, $S Q_{1}$ in Figure 2) to the floor median (for example, $F$ in Figure 2), the result will be a rightward policy move. ${ }^{25}$ In the second main category are policies that lie to the right of the current centre of legislative opinion $\left(S Q_{j}>F_{j}\right)$. If the legislature votes on a bill to change such a policy from the status quo (for example, $S Q_{2}$ in Figure 2) to the floor median $(F)$, the result will be a leftward policy move.

It follows from our analysis of blockout and roll zones that, leftist governments, such as depicted in Figure 2, move most policies leftward. That is, most policy changes will change status quos such as $S Q_{2}$ to $F$. Rightward policy moves within the blockout zone will be vetoed by the government. Some rightward policy moves will be possible, changing status quos to the left of $2 \mathrm{M}-\mathrm{F}$ in Figure 2 to $F$. In these cases, we expect large, if not unanimous coalitions to be in favour of the moves, making both the government and opposition parties better off. Thus, the only exceptions to the rule that leftist governments will move policy leftward should be combined with large, if not unanimous, votes. Similarly, most rightist party policy moves should be rightward or nearly unanimous. ${ }^{26}$ Thus:

H4) Policy should usually move leftward if the government is left-of-centre and rightward if the government is right-of-centre. Changes in government will, all else constant, change the direction of policy movement.

This result may seem obvious, but notice that, if the Floor Agenda Model holds, then policy moves will come from both directions, as shifting coalitions form and agree to move policy. It is only if the government forms an agenda cartel, and thereby agrees to avoid shifting coalitions, that a strong association between the political cast of the government and the direction of policy movement is to be expected. Thus, examining roll rates provides an appropriate test of whether the prohibition on 'changing majorities' to which Germany's governing parties typically agree is binding in practice.

\section{HYPOTHESES ABOUT DIVIDED GOVERNMENT}

In this section, we state several hypotheses about the effect of divided government (that is, divided control of the Bundestag and Bundesrat) in Germany. If an opposition party wields a veto in the second chamber, and the second chamber can block first-chamber proposals, then the party can use its veto to stop proposals that would roll it. If the second chamber holds only a dilatory or suspensory veto, the majority coalition there can use it to delay the government's enactments and may, by threatening to delay, extract concessions from the government. In this way, the majority coalition 
in the Bundesrat can reduce the offensiveness of some of the government's proposals and by so doing reduce the roll rates of their comrades in the Bundestag. Thus:

H5) Divided government should decrease the roll rates of opposition parties that hold a veto in the other chamber (for example, when they are in the majority in the other chamber), all else constant.

H6) We should see more unanimous or nearly unanimous votes during divided government, all else constant.

If the majority coalition in chamber A of a bicameral legislature can place items on the agenda of chamber $\mathrm{B}$, then divided government should lead to a loss of agenda control in chamber B. Proposals that would otherwise be blocked by the government or majority in chamber B will get some plenary time and could roll the majority or government parties. This is equivalent to a change in the structure of the first stage of the game described in the earlier section, whereby the government or majority parties no longer have a monopoly on the agenda. Instead, some fraction of the agenda is controlled by another party. Also, the opposition may use its power in the other chamber, either through gatekeeping or proposing, to create a bargain, or logroll, with the majority or governmental parties. This bargain may include placing items in the agenda that end up rolling the government or majority parties and/or moving policy away from the government/majority. Thus:

H7) Divided government should, all else constant, increase the roll rates of governmental parties.

H8) Divided government should reduce the proportion of proposals that move policy toward the ideal points of the government parties, all else constant.

DATA

We test these hypotheses using roll call votes recorded in the Bundestag between 1980 and 2002 for six legislative periods, ${ }^{27}$ namely the ninth through fourteenth Wahlpers. ${ }^{28}$ Recorded votes take place when a parliamentary group or 31 members request them and they usually concern hotly debated issues of major policy.

There were 701 recorded votes during from 1980 to 2002 (excluding confidence motions, veto overrides, and constitutional amendments, which require more than a simple majority of votes) and of these, 259 were final passage roll call votes on bills and committee recommendations. It is from these final passage votes that we calculate each party's roll rate and the direction of policy moves. ${ }^{29}$

Party $\mathrm{j}$ is rolled if and only if more of its members vote 'no' on the motion to pass a bill than vote 'yes' and the bill passes. ${ }^{30}$ Party j's roll rate is simply the total number of times it is rolled in a given time period, divided by the total number of votes held in that period.

In calculating roll rates, and later policy moves, a question arises about the time period to use. Calculating these measures for each Wahlper would seem natural and most of our results are presented on this basis. The problem is, however, that multiple Land elections take place during any given Wahlper, which are usually seen as tests of the federal government's popularity. These elections change the number of seats held 
by the federal government and opposition in the Bundesrat. These changes frequently affect whether the government faces unified or divided control of the Bundesrat. Changes in Bundesrat representation have also resulted from the addition of new Länder. In particular, German unification in 1990, by incorporating five eastern Länder, altered the political character of the Bundesrat. ${ }^{31}$ Therefore, each time the balance of power between government and opposition changes in the Bundesrat, we can have a new observation for each party and its roll rate. We call these time periods legislative sub periods. ${ }^{32}$ Thus, the dependent variable in the following analysis is either the roll rate of each party during each of the ninth to fourteenth Wahlpers, in which case we have 26 party-Wahlper observations, or the roll rate of each party during each legislative sub-period, in which case we have 78 party-sub-period observations.

There are five parties in the Bundestag during this period, namely the Christian Democratic Union (CDU/CSU), the Free Democratic Party (FDP), the Social Democratic Party (SPD), the Green Party (GRN), and the Party of Democratic Socialism (PDS). The PDS, as the successor to the SED, came into existence in 1990, with the unification of Western and Eastern Germany. The Greens gained representation starting with the tenth Wahlper.

During the ninth Wahlper, SPD and FDP began in government. In our analysis, Wahlper 9 includes only the SPD - FDP government (called Wahlper 9.1), before the change in government that took place in 1982, when CDU/CSU and FDP took over (there were only four votes during this second part of the Wahlper, not enough to create a Wahlper 9.2 for analysis). During legislatures 10-13, CDU/CSU and FDP constituted the government. With the fourteenth Wahlper, the SPD and Greens formed the new government. ${ }^{33}$

\section{BASIC RESULTS}

\section{Hypotheses $\mathrm{Hl}$ and $\mathrm{H} 2$}

Roll rates for the government and opposition parties in the Bundestag are given in column 3 in Table 1. As can be seen, the government parties' roll rate averages about 1 per cent. This average is substantively very close to zero and is on par with

TABLE 1

MEAN BUNDESTAG ROLL RATES FOR GOVERNMENT AND OPPOSITION PARTIES WHEN IN MINORITY VS. IN MAJORITY IN THE BUNDESRAT

\begin{tabular}{lcccc}
\hline & & \multicolumn{2}{c}{ Party in Bundesrat } & \\
\cline { 3 - 4 } & & In minority & In majority & Mean roll rates \\
\hline Party in Bundestag & Out of government & 0.81 & 0.66 & 0.72 \\
& & $(0.14)$ & $(0.14)$ & $(0.15)$ \\
& & 9 observations & 16 observations & 25 observations \\
& In government & 0.02 & 0 & 0.01 \\
& & $(0.03)$ & $(0)$ & $(0.02)$ \\
& 12 observations & 8 observations & 20 observations \\
\hline
\end{tabular}

Note: only trends with eight or more final passage votes included in this analysis. Cell entries give means, standard deviations (in parentheses), and the number of observations. 
the roll rates of other government parties in parliaments around the world. Further analysis shows that the government's rolls occurred only during divided government and were on substantively unimportant issues, so the consequential roll rate for the government is virtually zero. ${ }^{34}$

As a rule, governmental parties vote together; in some rare instances, however, one partner gets rolled while the other does not. In the twelfth Wahlper, during the CDU and FDP government, CDU got rolled while FDP did not, on two abortion policy issues. In these instances, FDP voted with the opposition, defecting on its coalition partner. In the thirteenth Wahlper, there was one vote, on parliamentary reform, where FDP was rolled and CDU was not, and in the fourteenth Wahlper, there was one vote, on the issue of embryonic cell research, where the Greens were rolled but SPD was not.

What do these low roll rates for government parties mean? Thinking not just of Germany, but of governments/majorities in general, low government roll rates mean either that the government has structural advantages in setting the agenda; or that the governing coalition votes cohesively on agenda-setting votes; or both. The mix of structural advantage and disciplined voting can vary from case to case. For example, the majority party in the US House of Representatives relies less on strict discipline and more on structural advantages than does the governing majority in the Bundestag. US majorities take all committee chairs, whereas German majorities take only a proportional share; and US majorities take a super-proportional share of seats on the Rules Committee, whereas German majorities take only a proportional share of seats on the Council of Elders; amendments to bills in the US House often roll the majority party, but the government is never rolled on amendments in the Bundestag. ${ }^{35}$

Although it is true that German majorities rely relatively more on discipline and less on structural advantages than do majorities in the US House, we would stress that negotiating the plenary agenda off the floor (in the Council of Elders and, before that, in talks among the governing partners) makes it easier to manage the agenda than would a system in which the agenda were routinely constructed on the floor, as the latter system presents a greater risk that a clever opposition motion can divide the government. If, for example, one coalition partner champions farmers' subsidies but has agreed not to pursue increases during the current government, it will not be happy to be forced repeatedly to vote down motions, introduced by a mischievous opposition, to consider such subsidies. Lessening the opposition's opportunities to force votes on such mischievous motions is one advantage of endowing bodies like the Council of Elders with agenda-setting authority.

For the opposition parties, the average roll rate is much higher, at 72 per cent. A large part of these opposition rolls are votes on yearly budgets, but also on major policy areas such as tax laws, civil rights (human rights policy), reduction and relocation of troops and UN army participation, regional planning and urban affairs, labour market policy, social security, economic growth and state expenditure, nursing care, abortion regulation, environmental issues, agriculture, immigration, health insurance reform, privatisation and pension reform.

\section{Hypothesis $\mathrm{H3}$}

In order to test hypothesis $\mathrm{H} 3$, we first needed to estimate the distance of opposition (and governmental) parties from the chamber median on a left-right policy dimension. 
However, because we do not have a measure of ideological distance that has interval level properties, we have used data from Budge et al. ${ }^{36}$ for the ninth to fourteenth Wahlpers to identify the party farthest away (both on the left and on the right) from the government coalition in each Wahlper. We call these variables DISTANCE- $\mathrm{L}_{\mathrm{jt}}$ (for the farthest left party) and DISTANCE- $\mathrm{R}_{\mathrm{jt}}$ (for the farthest right party). ${ }^{37} \mathrm{We}$ also estimate the distance of governmental parties from the chamber median (DISTANCE_GOVT $\mathrm{jt}_{\mathrm{jt}}$ ), and we expect to see a coefficient on this variable that is not significantly different from $0 .{ }^{38}$

For a visual representation of how roll rates vary as a function of being in and out of government in the Bundestag and as a function of the parties' placement on the leftright axis, we graph Wahlpers 12 and 13 in Figures 4 and 5. Parties are ranked according to the left-right score assigned in the Manifesto Party Project by Budge et al. ${ }^{39}$ This variable, which we refer to as the MPP score, is shown on the $\mathrm{x}$-axis, while roll rates, varying from 0 to 1 , are on the y-axis. ${ }^{40}$

These graphs illustrate visually the results we find in the following regression, namely that government roll rates are not significantly different from 0 , that opposition roll rates are significantly different from 0 , and that roll rates of opposition parties increase the further away the party is from the governmental coalition median. The one deviation from the finding that opposition parties' roll rates increase the further away they are from the left of the government is found in Wahlper 12 (Figure 4). The SPD has a lower roll rate here because the opposition outnumbers the government in the Bundesrat during this period of divided government.

These graphic results and their statistical significance are confirmed in the regression below. We regressed ROLL $\mathrm{RATE}_{\mathrm{j}}$, the roll rate of party $\mathrm{j}$ during 
Wahlper $t$, on IN_GOVT_BUNDESTAG $\mathrm{j}_{\mathrm{jt}}, \quad$ DISTANCE-L $\mathrm{L}_{\mathrm{jt}}, \quad$ DISTANCE- $\mathrm{R}_{\mathrm{jt}}$, DISTANCE-GOVT $_{\mathrm{jt}}$ and TREND $_{\mathrm{j} t}$, the last variable to account for the downward trend evident in German roll rates for all parties over this time period. ${ }^{41}$ This gives us equation (1):

$$
\begin{aligned}
\text { ROLL RATE }_{\mathrm{jt}}= & \alpha+\beta_{1} \text { IN_GOVT_BUNDESTAG }_{\mathrm{jt}} \\
& +\beta_{2} \text { DISTANCE-L }_{\mathrm{jt}}+\beta_{3} \text { DISTANCE-R }_{\mathrm{jt}} \\
& +\beta_{4} \text { DISTANCE-GOVT }_{\mathrm{jt}}+\beta_{5} \text { TREND }_{\mathrm{jt}}+\varepsilon_{\mathrm{jt}},
\end{aligned}
$$

To estimate this equation, we employed the extended beta binomial regression method (EBB) suggested by $\mathrm{King}^{42}$ and Palmquist, ${ }^{43}$ which deals with situations where the dependent variable is an aggregation of individual binary choices that are likely not independent of each other. ${ }^{44}$ The results in Table 2 show that, as hypothesised, the opposition party farthest left from the government exhibits a significantly higher roll rate than the opposition parties closer to the government. Again, the one deviation from the finding that opposition parties' roll rates increase as they are further away to the left of the government is to be found during divided government in Wahlper 12 .

The coefficient on the variable DISTANCE- $\mathrm{R}_{\mathrm{jt}}$ is not significant. That is, there was no difference in the roll rates for the two opposition parties, CDU and FDP, in the fourteenth Wahlper (in which the SPD and Greens formed the government).

The variable that distinguishes the distance of governmental parties from the chamber median (DISTANCE_GOVT $\mathrm{j}_{\mathrm{jt}}$ ), as expected, is not statistically different than zero. We can also reject the null hypothesis that the effect of distance from the 
TABLE 2

ROLL RATES BY PARTY-WAHLPER FOR GOVERNMENT AND OPPOSITION

PARTIES, ESTIMATED BY EBB

\begin{tabular}{|c|c|}
\hline Dependent variable: party j's roll rate in Wahlper $t$ & $\begin{array}{c}\text { Coefficient } \\
\text { (std. error) } \\
\text { Z statistic }\end{array}$ \\
\hline IN_GOVT_BUNDESTAG ${ }_{j t}$ & $\begin{aligned}-5.072 \\
\quad(.551) \\
-9.20^{* * *}\end{aligned}$ \\
\hline $\begin{array}{l}\text { DISTANCE- } \mathrm{L}_{\mathrm{jt}} \\
\text { (Opposition party ranked furthest to the left from government in each } \\
\text { Wahlper, by Budge } \text { et al.) }\end{array}$ & $\begin{array}{l}.738 \\
(.229) \\
3.21^{* * *}\end{array}$ \\
\hline $\begin{array}{l}\text { DISTANCE- } \mathrm{R}_{\mathrm{jt}} \\
\text { (Opposition party ranked furthest to the right from government in } \\
\text { each Wahlper, by Budge et al.) }\end{array}$ & $\begin{array}{r}-.267 \\
(.37) \\
-.72\end{array}$ \\
\hline $\begin{array}{l}\text { DISTANCE-GOVT }_{\mathrm{jt}} \\
\text { (Non-median government party in each Wahlper, by Budge et al.) }\end{array}$ & $\begin{array}{l}.075 \\
(.842) \\
.09\end{array}$ \\
\hline $\begin{array}{l}\text { TREND }_{\mathrm{jt}} \\
\text { (Wahlper) }\end{array}$ & $\begin{aligned} & -.084 \\
& (.021) \\
- & 3.99^{* * *}\end{aligned}$ \\
\hline Constant & $\begin{array}{l}1.818 \\
(.318) \\
5.71^{* * *}\end{array}$ \\
\hline $\begin{array}{l}\text { LR Chi }{ }^{2} \\
\mathrm{~N}\end{array}$ & $\begin{array}{r}740.21 \\
23\end{array}$ \\
\hline
\end{tabular}

** indicates $p<.05$; ${ }^{* * *}$ indicates $p<.01,1$-tailed test

chamber median on the roll rates for opposition parties is 0 or negative. These results serve to validate the key test of our theory, which is the comparative static presented in hypothesis $\mathrm{H} 3$.

\section{Hypothesis H4}

As previously stated, policy should move toward the government and away from the opposition, but divided government should decrease the proportion of policy moves toward the government. In order to compute policy moves and their direction, we computed a one-dimensional Optimal Classification on German roll call votes and used this, together with the pattern of yea and nay votes, to determine a cutpoint for each vote. $^{45}$ The cutpoint determines the point in policy space that separates the yes and no votes. Figure 6 offers an example of how cutpoints can help us identify policy moves. This figure shows a typical move toward the government and away from opposition parties during Wahlper 12.

During Wahlper 12, with the FDP and CDU/CSU in government, the left-right ranking of parties produced by $\mathrm{OC}$ is presented in Figure 6. Knowing that both FDP and CDU/CSU voted in favour of the bill, that all opposition parties voted against the bill, and that the bill passed, we can conclude that the policy moves toward the governmental parties and away from the opposition parties. ${ }^{46}$ Similarly for all Wahlpers, we look at bills that passed and coded whether the policy move was towards the 
government and away from the opposition or the reverse. We only consider bills that passed for the policy moves analysis, since failed bills cannot be policy moves.

In this analysis, we also include only those bills where the cutpoint indicates an unambiguous move toward either the government or the opposition parties. We do not utilise the very few votes that split the government coalition because we cannot always determine a direction of policy change in these cases. ${ }^{47}$ We hope to explore in more depth in future research the dynamics of coalition disagreements and how agenda control breaks down when coalition partners disagree. For now, we discard these moves as ambiguous from the point of view of our theory. We also exclude unanimous votes, where policy moved toward both government and opposition.

Table 3 presents the proportion of policy moves toward the government for each Wahlper.

Overall, for Wahlpers 9-14, the proportion of policy moves toward the government is 99 per cent; in fact there are only two policy movements away from the governmental coalition parties out of 196 policy moves. There is one policy move opposed by both government parties (CDU/CSU and FDP) during Wahlper 13 that concerned criminal law, and one policy move opposed by both government parties, the SPD and Greens during the fourteenth, on the issue of the reconstruction of the Palace of the Kaiser.

\section{RESULTS REGARDING DIVIDED GOVERNMENT}

We have argued above that divided government may increase government roll rates (H5), increase unanimous roll calls (H6), decrease opposition roll rates (H7), and decrease policy moves toward the government (H8). Before examining the empirical 
TABLE 3

PROPORTION OF POLICY MOVES TOW ARD THE GOVERNMENT

\begin{tabular}{lccccccc}
\hline & $\begin{array}{c}\text { Wahlper } \\
\mathbf{9 . 1}\end{array}$ & $\begin{array}{c}\text { Wahlper } \\
\mathbf{1 0}\end{array}$ & $\begin{array}{c}\text { Wahlper } \\
\mathbf{1 1}\end{array}$ & $\begin{array}{c}\text { Wahlper } \\
\mathbf{1 2}\end{array}$ & $\begin{array}{c}\text { Wahlper } \\
\mathbf{1 3}\end{array}$ & $\begin{array}{c}\text { Wahlper } \\
\mathbf{1 4}\end{array}$ & Total \\
\hline $\begin{array}{l}\text { Moves toward the } \\
\text { government (\%) }\end{array}$ & 100 & 100 & 100 & 100 & 98 & 96 & 99 \\
$\begin{array}{c}\text { Moves away from the } \\
\text { government (\%) }\end{array}$ & 0 & 0 & 0 & 0 & 2 & 4 & 1 \\
\begin{tabular}{l} 
Total number of votes \\
\hline
\end{tabular} & 9 & 33 & 54 & 30 & 47 & 23 & 196 \\
\hline
\end{tabular}

evidence regarding these propositions, we should note that the effects of divided government may be lessened by the means through which the government overcomes divided government situations in Germany. These include allocation of funds to Land governments, which is key for the government to buy off votes in the Bundesrat. ${ }^{48}$ Some examples are famous. In 1999, on the decision of the German nationality law, the SPD-Green government negotiated a deal with the SPD-FDP government of Rhineland-Palatinate and thereby secured a majority in the Bundesrat. Similarly, in July 2000, on tax reform, the government secured a Bundesrat majority by 'buying off' votes. As in American politics, the coin of the realm consisted of special favours and projects.

\section{Hypotheses $\mathrm{H} 5$ and $\mathrm{H7}$}

This section compares roll rates during unified and divided government. Coding occurrences of divided government, however, can be problematic. The power of the Länder in the Bundesrat provides an institutional basis for divided government that is lacking in most parliamentary regimes. The voting unit in the Bundesrat is the Land, not the party. So, we coded the composition of the Bundesrat by computing the number of seats held by the governmental parties together as well as the number of seats held by opposition parties together. The coding of Land election results indicates parties in government at the Land level. This was a rather complicated process because Land government coalitions may not be entirely identical with the Bundestag coalitions, or they may be a mix of opposition and government parties, as in a grand coalition of the SPD and CDU.

Following Sturm's ${ }^{49}$ calculations, we considered a Land to be controlled by the government if the Land coalition was composed of: (1) a single governmental party; or (2) a number of governmental parties (some or all); or (3) one or more governmental parties plus some (small) regional party (that may not have seats in the Bundestag; this applies primarily to SPD-PDS coalitions). On the side of the opposition, we considered as opposition-controlled those Land governments made up of: (1) a single opposition party; or (2) a number of opposition parties (some or all). ${ }^{50}$

A party is coded in the majority in the Bundesrat if together with its coalition partners it holds more seats than the opposition parties. Thus, the status of parties in the second chamber is a dummy variable indicating whether each party and its coalition partners had a majority of seats in the second chamber.

Looking back, Table 1 displays the mean roll rates, standard deviations (in parentheses), as well as the number of observations for each category, for government and 
opposition parties, when they hold a majority in the Bundesrat and when they do not. We see that holding a majority in the second chamber does in fact decrease opposition party roll rates by 15 percentage points. By contrast, the increase in the roll rates for the parties within the government is small (from 0 to 2 per cent) when those parties do not control a majority of votes in the Bundesrat. These results suggest that the Bundesrat does exercise some degree of agenda power and that the topic deserves further study.

Changes in the composition of the governing coalition should also change each party's roll rate. Thus, when the CDU/CSU-FDP coalition loses its majority and is replaced by the SPD-Green coalition, we should see a corresponding change in each of the four parties' roll rates. Roll rates for the PDS, which is never in government, by contrast, should not change. Roll rates for the CDU/CSU and FDP increase from an average of 2 per cent during Wahlper 13 to 49 per cent in Wahlper 14 when these parties no longer form the government. By contrast, the roll rates for the Greens and SPD go from 69 per cent and 52 per cent respectively in the thirteenth Wahlper to 4 per cent and 2 per cent respectively in the fourteenth Wahlper. The roll rate for the PDS, whose status did not change during this period, remained stable between 71 per cent to 74 per cent from the thirteenth to the fourteenth Wahlper.

To test the effect of joining and leaving the government in both chambers, we compare the classic coalition partners - CDU/CSU and FDP, who were in government together (Wahlpers 10-13), as well as SPD and Greens, who were in government together as of 1998 (Wahlper 14). We estimate two regressions, based on the same equation (3):

$$
\begin{aligned}
\operatorname{ROLL~RATE}_{\mathrm{jt}}= & \alpha+\beta_{1} \text { IN_GOVT_BUNDESTAG } \\
& +\beta_{2} \text { IN_GOVT_BUNDESRAT }+\varepsilon,
\end{aligned}
$$

In equation (3), IN_GOVT_BUNDESTAG is a dummy indicating if the party is in government or out of government in the Bundestag and IN_GOVT_BUNDESRAT is a dummy indicating if the party is in government (that is, in the majority coalition) or out of government in the Bundesrat. Using EBB regression, we generated the results presented in Table $4 .{ }^{51}$

Moving in and out of government in the Bundestag significantly reduces the roll rates of the coalition partners CDU/CSU and FDP, although moving in and out of the majority in the Bundesrat, in and of itself, does not have a significant effect on CDU/CSU and FDP roll rates. This is largely the result of this coalition's control over the Bundestag for most of the period under study.

If we run the same regression for the other coalition partners, the SPD and Greens, which are in government only during Wahlper 14, we see a much higher effect of the Bundesrat status change, which is shown by results presented in Table 5. ${ }^{52}$ These results again suggest an effect for divided government.

\section{Hypothesis H6}

We should also see more unanimous votes on major policy issues during divided government. There are six unanimous votes during the six legislatures we examined and all occurred during periods of divided government. Inherently consensual issues are either 
TABLE 4

THE EFFECT OF CDU/CSU-FDP BEING IN GOVERNMENT IN THE BUNDESTAG AND BUNDESRAT ON THEIR ROLL RATES

\begin{tabular}{lc}
\hline & Coefficient $(\mathbf{Z}$ score) \\
\hline IN_GOVT_BUNDESTAG & $-4.474^{* * *}(-9.66)$ \\
IN_GOVT_BUNDESRAT & $-.694(-1.85)$ \\
Constant & $.35(1.21)$ \\
Log likelihood & -90.432408 \\
Pseudo R ${ }^{2}$ & .45 \\
N & 32 \\
\hline
\end{tabular}

**indicates $p<.05 ;{ }^{* * *}$ indicates $p<.01,1-$ tailed test.

more likely to be taken up under divided government, or inherently conflictual issues are more likely to be compromised under divided government.

\section{Hypothesis $H 8$}

Does divided government decrease the proportion of policy moving towards the government as predicted? Table 6 shows the proportion of policy moves toward the government during divided and unified government.

During unified government, the proportion of moves toward the government is 100 per cent during the six legislative periods. This figure drops to 98 per cent during divided government - that is, there were only two policy moves away from the government during Wahlpers 13 and 14 and both occurred under divided government.

Further, under centre-right CDU/CSU-FDP coalitions (Wahlpers 10-13), government policy moved rightward in 99.5 per cent of cases, while when the SPD-FDP and SPD-Green centre-left coalitions were in government (Wahlpers 9 and 14), policy moved leftward 98 per cent of the time. We expected that leftist coalitions should move policy leftward and rightist coalitions should move policy rightward. This differs from the expectations under the Floor Agenda Model, where policy change should be determined simply by the distribution of status quo points. ${ }^{53}$

TABLE 5

THE EFFECT OF COALITION PARTNERS SPD AND GREENS BEING IN GOVERNMENT IN THE BUNDESTAG AND BUNDESRAT ON ROLL RATES

\begin{tabular}{lc}
\hline & Coefficient (Z score) \\
\hline IN_GOVT_BUNDESTAG & $-5.308^{* * *}(-7.92)$ \\
IN_GOVT_BUNDESRAT & $-1.937^{* * *}(-5.43)$ \\
Constant & $2.453^{* * *}(7.64)$ \\
Log likelihood & -208.28649 \\
Pseudo R & .37 \\
$\mathrm{~N}$ & 32 \\
\hline
\end{tabular}

${ }^{* *}$ indicates $p<.05 ;{ }^{* * *}$ indicates $p<.01,1-$ tailed test. 
TABLE 6

PROPORTION OF POLICY MOVES TOWARD THE GOVERNMENT DURING DIVIDED GOVERNMENT

\begin{tabular}{|c|c|c|}
\hline & Divided government & Unified government \\
\hline Moves toward the government & $\begin{array}{c}98 \% \\
\text { (99 policy moves) }\end{array}$ & $\begin{array}{c}100 \% \\
\text { (95 policy moves) }\end{array}$ \\
\hline Moves away from the government & $\begin{array}{c}2 \% \\
\text { (2 policy moves) }\end{array}$ & $\begin{array}{c}0 \% \\
\text { (0 policy moves) }\end{array}$ \\
\hline
\end{tabular}

\section{CONCLUSIONS}

In this article, we find strong evidence of monopoly legislative agenda control by government parties in the Bundestag. First, the government parties have near-zero roll rates, while the opposition parties are often rolled over half the time. Second, opposition parties' roll rates increase with the distances of each party from the floor median, while roll rates for government parties do not respond to changes in their distance from the floor median. Third, almost all policy moves are towards the government coalition and the only exceptions occur during periods of divided government. Fourth, changes in government and opposition in the Bundestag cause changes in roll rates and the direction of policy movement, with roll rates for government parties skyrocketing when they fall into the opposition and vice versa for opposition parties, while policy movements go from being nearly 100 per cent rightward when there is a rightist government to 100 per cent leftward under a leftist government.

These results for Germany are similar to those previously found in Japan, ${ }^{54}$ the $\mathrm{US}^{55}$ and several other assemblies. Germany conforms to the 'procedural cartel thesis' we articulated earlier in the paper.

We have also examined the effect that divided government has on the legislative process. First, we have examined whether being in the majority in the Bundesrat can reduce the roll rate of parties, which are out of government in the Bundestag and found a difference in the expected direction. Second, we examined whether divided government reduces the proportion of policy moves toward the government and again found a difference in the expected direction (not significant). Third, we examined whether voting is more consensual during divided government and found that all the unanimous votes in our dataset occur during divided government.

It is worth noting that the effects of divided government might be greater than we have documented here, as the effects may be masked by actors' strategic behavior. For instance, unanimous bills increase in frequency under divided government, presumably because the government compromises with the coalition controlling the Bundesrat. However, governmental agenda setters may also strategically refrain from introducing bills that cannot pass in the Bundesrat. ${ }^{56}$ Such restraint would change the government's agenda in a way not captured by our battery of statistics.

\section{NOTES}

The authors thank Thomas Saalfeld for supplying his data on Bundestag roll call votes; and Adriana Bejan, Cheryl Boudreau, Nick Weller, and Markus Wendler for research assistance. The authors acknowledge 
funding from the National Science Foundation, grant numbers SBR-9422831 and SES-9905224, from the UCSD Committee on Research, and from the Chancellor's Associates Chair at UCSD. Previous versions of this article were presented at a conference on legislative politics in 2004 sponsored by the UCSD Public Policy Research Project and at the 2005 Annual Meeting of the American Political Science Association, Washington DC. All data used in this paper and all results reported can be found and downloaded at www.settingtheagenda.com.

1. Recent studies of backbench rebellion show that there is indeed diversity of opinion even within the majority party in the UK. (See, e.g., Giacomo Benedetto and Simon Hix, 'The Rejected, the Ejected, and the Dejected: Explaining Labour Rebels in the House of Commons', manuscript on file with authors (2005).)

2. For interesting discussions of discipline and agenda control, see Simon Hix, Abdul Noury, and Gerard Roland, Democracy in the European Parliament, manuscript on file with authors (Forthcoming) and Gary W. Cox and Mathew D. McCubbins, Setting the Agenda: Responsible Party Government in the US House of Representatives (Cambridge: Cambridge University Press, 2005).

3. Cf. John Huber, 'The Vote of Confidence in Parliamentary Democracies', American Political Science Review, 90 (1996), pp.269-82.

4. Details on Bundestag procedure described here are drawn from Rupert Schick and Wolfgang Zeh, The German Bundestag, Functions and Procedures (Neue Darmstädter Verlagsanstalt: Rheinbreitbach, 1999).

5. For a discussion of the persistence of procedural consensus in the Bundestag, see Gerhard Loewenberg and Tracy H. Slagter, 'The Persistence of Procedural Consensus in the German Bundestag', Working paper (2005).

6. Gerhard Loewenberg, 'Agenda Setting in the German Bundestag: Origins and Consequences of Party Dominance', Journal of Legislative Studies 9 (2003), pp.17-31; Thomas Saalfeld, 'The West German Bundestag after 40 Years: The Role of Parliament in a "Party Democracy", Parliaments in Western Europe, 13(1990), pp.68-89.

7. For an interesting discussion of how German MPs commit to consensual policymaking in committees, but remain adversarial in opposition-government relationships at the plenary level, see Thomas Saalfeld, 'Professionalisation of Parliamentary Roles in Germany: An Aggregate Level Analysis, 1949-94', in Members of Parliament in Western Europe: Roles and Behaviour (eds.), Wolfgang C. Müller and Thomas Saalfeld (London: Frank Cass Publishers, 1997).

8. Loewenberg, 'Agenda Setting in the German Bundestag', p.22; Schick and Zeh, The German Bundestag, Functions and Procedures, p.31.

9. It is up to the vote of the Bundestag to decide on the number, size and specific composition of the committees (which is proportional to the size of parliamentary groups).

10. The Council of Elders is composed of the President, the deputies and 23 members of the Bundestag appointed by the parliamentary groups in proportion to their size. These include all the parliamentary secretaries or whips of each parliamentary group.

11. Loewenberg, 'Agenda Setting in the German Bundestag'.

12. Ibid., p.22.

13. Werner J. Patzelt, 'Chancellor Schröder's Approach to Political and Legislative Leadership', German Politics, 13(2004), pp.268-99, 272.

14. While regional politics remains the most important influence on Bundesrat decision-making, partisan politics has come to play an important role too. Since the Bundesrat's consent on bills passed by the Bundestag is required in many policy areas, when the two legislative majorities are incompatible, the opposition in the Bundesrat can veto legislation in hope of extracting policy concessions (an absolute majority vote of the Bundesrat is required for about 60 per cent of all legislation). In the 1970s and 1980 s, the partisan lines in the Bundesrat were quite clear, as few Land delegations were mixed coalitions of government and opposition parties. But by the 1990s, mixed Land coalitions had become a permanent feature of German federalism (See Roland Sturm, 'Divided Government in Germany: The Case of the Bundesrat', in Robert Elgie (ed.), Divided Government in Comparative Perspective. (New York: Oxford University Press, 2001), pp.167-81.) Because the Länder cast their weighted votes as a bloc (Art. 51), the federal government is constrained by the fact that it cannot buy off the votes of individual members. Instead, it must convince certain Länder to support its bills. This can be achieved by rewarding these Länder with distributive benefits. Scholars criticise the partisanship of the Bundesrat and many regard divided government as a basic flaw of the German system. The question of the effects of divided government is whether the use of vetoes leads to gridlock, or to consensus politics. First, the use of veto politics can lead to gridlock. During divided government we see the use of veto politics - when the opposition in the Bundesrat can block bills by vetoing them. If the opposition holds two-thirds in the Bundesrat, its use of veto politics is very powerful, because the Bundestag needs to match the Bundesrat veto by overriding it with a two-thirds majority 
(Thomas König, Till Blume, and Bernd Luig, 'Policy Change without Government Change? German Gridlock after the 2002 Election', German Politics, 12 (2003), pp.86-146). Such veto politics can lead to political immobilism (Gerhard Lehmbruch, 'Institutional Linkages and Policy Networks in the Federal System of West Germany', Publius: The Journal of Federalism 19 (1989), pp.221-35; Fritz Scharpf, 'The Joint-Decision Trap: Lessons from German Federalism and European Integration', Public Administration 66 (1988), pp.239-78; Sturm, 'Divided Government in Germany'). Second, situations of divided government can lead to compromise and consensus (Cf. Sturm, 'Divided Government in Germany'). The mediation (conference) committee acts as a consensus arena, trying to solve differences between the two chambers. For instance from 1972 to 1980, 17 out of 34 Bundesrat vetoes were overcome with the use of conference committee work. Between 1990 and 1998, the government rarely held a majority on the conference committee, yet 53 out of 80 Bundesrat vetoes were overcome through compromise (Ibid.).

15. Patzelt, 'Chancellor Schröder's Approach to Political and Legislative Leadership'.

16. By a pivotal party we mean one whose withdrawal would deprive the government of a majority in the assembly.

17. We shall here ignore the possibility that $C_{k}$ 's coalition partners might send a bill to the floor even after $\mathrm{C}_{\mathrm{k}}$ has 'vetoed' it, perhaps in the belief that $\mathrm{C}_{\mathrm{k}}$ is bluffing and will not really bring down the government over this issue. See Cox and McCubbins, Setting the Agenda for models in which vetoes are not so cut and dried.

18. Patzelt, 'Chancellor Schröder's Approach to Political and Legislative Leadership', p.273.

19. Octavio Amorim Neto, Gary W. Cox, and Mathew D. McCubbins, 'Agenda Power in Brazil's Câmara dos Deputados, 1989-98', World Politics, 55 (2003), pp.550-78; Gary W. Cox and Mathew D. McCubbins, 'Agenda Power in the US House of Representatives, 1877 to 1986', in Party, Process, and Political Change in Congress: New Perspectives on the History of Congress (eds.) David Brady and Mathew D. McCubbins, (Stanford: Stanford University Press, 2002); Cox and McCubbins, Setting the Agenda.

20. Eric C. Browne and Mark N. Franklin, 'Aspects of Coalition Payoffs in European Parliamentary Democracies', American Political Science Review 67 (1973), pp.453-69; Ian Budge and Hans Keman (eds.), How Party Government Works: Testing a Theory of Formation, Functioning, and Termination in 20 Democracies (Oxford: Oxford University Press, 1990), Ch.4; Michael Laver and Norman Schofield, Multiparty Government: the Politics of Coalition in Europe (Oxford: Oxford University Press, 1990), Ch.7; Royce Carroll and Gary W. Cox, 'The Logic of Gamson's Law: Pre-Electoral Coalitions and Portfolio Distribution', unpublished typescript, University of California, San Diego (2005).

21. Cf. Sebastian Saiegh, 'Government Defeat: Coalitions, Responsiveness, and Legislative Performance', Ph.D. Dissertation, New York University (2004).

22. When we refer to the ideal point of a party, we mean the median of the ideal points of all MPs of that party.

23. If the government can bring a bill to the floor and protect it completely from amendments (as closed rules in the US House allow), then some status quo points in the region (2M $-\mathrm{F}, \mathrm{M})$ can be addressed by the government. For example, $\mathrm{M}$ would agree to change a status quo at $\mathrm{M}-\mathrm{e}$ to some point in the interval $[\mathrm{M}, \mathrm{M}+\mathrm{e})$. If $\mathrm{F}$ and $\mathrm{M}$ can agree on single such point, they can bring in a bill and pass it.

24. We should hasten to note that these predictions that 'the majority party never gets rolled' are similar in analytic status to other predictions drawn from complete information models, in which actions are costless, such as 'there is never any war', or 'there are never any vetoes' (Cf. Charles M. Cameron, Veto Bargaining: Presidents and the Politics of Negative Power (Cambridge: Cambridge University Press, 2000)). Cox and McCubbins, Setting the Agenda explore a model with costly action in Chapter 6 and one with incomplete information in Chapters 8 and 9 of that book, showing that the main results derived here are largely preserved.

25. A prime example is the Schröder government's pursuit of labour market and welfare reform (Agenda 2010) against the will of many Bundestag members of its own party.

26. This is indeed, precisely the pattern that Cox and McCubbins, Setting the Agenda, Ch.9 found for the US House.

27. Note that our dataset is constructed from the Bundestag roll call votes that Thomas Saalfeld, Parteisoldaten und Rebellen. Eine Untersuchung zur Geschlossenheit der Fraktionen im Deutschen Bundestag (1949-1990) (Opladen: Leske u. Budrich, 1995) collected and analysed.

28. Wahlper means 'legislative period' - that is, the period between governments. This would be equivalent to a Congress in the American sense. The recorded votes can be found in Verhandlungen des Deutschen Bundestages, Stenographische Berichte - a publication of the Bundestag equivalent to the Congressional Record in the US.

29. The assumption is that final passage votes are sincere reflections of preference, as there is no advantage to strategic action at the final stage of the game. Other votes, on amendments, procedure and so forth, 
may be strategic and thus, we cannot accurately evaluate preferences and thus cannot determine rolls, the direction of policy movements, etc.

30. Simply comparing the number of 'yeas' and 'nays' can be criticised for ignoring instances where a large majority of the party chooses to abstain, because abstention might be an important strategic choice. By abstaining, a party might prevent the necessary support for passage; thus, votes on which the party abstains that ultimately pass could be 'possible rolls'. We also calculated expanded roll rates that included 'possible rolls' as rolls. The results are still consistent with our hypotheses. Adding possible rolls does not change numbers much - it only increases the roll rates of federal opposition parties that are not in government in the second chamber from 0.73 to 0.77 and the roll rates of opposition parties that are in Land governments in the second chamber from 0.60 to 0.65 . There are no changes to the roll rates of governmental parties.

31. Thomas König and Thomas Bräuninger, 'Power and Political Coordination in American and German Multi-chamber Legislation', Journal of Theoretical Politics 8(1996), pp.331-60.

32. Because some of these legislative subperiods included very few votes, we have dropped all the subperiods with less than eight final passage votes, leading to a total number of 34 remaining legislative period-party observations.

33. Information on seats held in the Bundestag and Bundesrat were found in Wahlergebnisse in Deutschland 1946-2003 (Mannheim: Forschungsgruppe Wahlen e. V., 2003).

34. For example, during Wahlpers 9-13, there was only one vote (on an issue of criminal law) where both governmental parties, CDU/CSU and FDP, were rolled. During the fourteenth Wahlper, there was again only one vote (on the issue of the rebuilding of the Palace of the Kaiser) where both governmental parties, SPD and the Greens, were rolled.

35. Just as we offer this brief comparison of the US and Germany, so too have other scholars situated Germany in a broader comparative context (see, e.g., Russell Dalton, Democratic Challenges, Democratic Choices: The Erosion in Political Support in Advanced Industrial Democracies (Oxford: Oxford University Press, 2004) and Wolfgang C. Müller and Kaare Strøm. Coalition Governments in Western Europe, (Oxford: Oxford University Press, 2000)).

36. Ian Budge, Hans-Dieter Klingemann, Andrea Volkens, Judith Bara and Eric Tanenbaum, Mapping Policy Preferences, Estimates for Parties, Electors, and Governments 1945-1998, (Oxford: Oxford University Press, 2001).

37. The farthest left parties were the PDS in the twelfth, thirteenth, and fourteenth Wahlpers and the Greens in the tenth and eleventh Wahlpers. The farthest right party was the CDU/CSU in the ninth and fourteenth Wahlpers; indeed, these were the only two Wahlpers where there existed a farthest right party that was not in the government.

38. For our DISTANCE_GOVT measure, we treat the interior government party as the median and the exterior government party as non-median; therefore, we need only to identify and distinguish those government parties that are not the median in each Wahlper. Specifically, these non-median government parties are the SPD in the ninth Wahlper, the CDU/CSU in the tenth and thirteenth Wahlpers, the FDP in the eleventh and twelfth Wahlpers, and the Greens in the fourteenth Wahlper. We use this ordinal DISTANCE_GOVT variable as a proxy for distance because there does not exist a cardinal measure.

39. Budge et al., Mapping Policy Preferences.

40. Throughout, we treat the MPP score as an ordinal ranking, including in Figures 4 and 5.

41. We drop the ninth Wahlper from the regression, as there is only one opposition party, so we are unable to distinguish a measure of distance among the opposition parties.

42. Gary King, Unifying Political Methodology: The Likelihood Theory of Statistical Inference (Cambridge: Cambridge University Press, 1989; reprinted, Ann Arbor: University of Michigan Press, 1998).

43. Bradley Palmquist, 'Analysis of Proportion Data', paper Prepared for the Annual Meeting of the Political Methodology Society, College Station Texas, 15-19July (1999).

44. Extended beta binomial (EBB) is an estimation technique used originally in toxicology studies in which there are both individual and group effects of a treatment. In studies of parliaments, we believe EBB is an appropriate technique because there are both individual and parliament-level factors that influence the probability of being rolled (for more on EBB, see J.K. Haseman and L.L. Kupper, 'Analysis of Dichotomous Response Data from Certain Toxicological Experiments', Biometrics, 35(1979), pp.281-93; L.L. Kupper and J.K. Haseman, 'The Use of a Correlated Binomial Model for the Analysis of Certain Toxicological Experiments', Biometrics, 34(1978), pp.69-76; D.A.Williams, 'The Analysis of Binary Responses from Toxicological Experiments Involving Reproduction and Teratogenicity', Biometrics, 31(1975), pp.949-52.

45. To estimate policy moves we used a scaling method called Optimal Classification (OC), developed by Keith T. Poole, Spatial Models of Parliamentary Voting (Cambridge: Cambridge University Press, 2005) for scaling roll call votes in legislatures. See his website at http://www.voteview.com/ 
Optimal_Classification.htm. To estimate party positions we used all 556 recorded votes during the eleventh through fourteenth Wahlpers.

46. OC also makes few classification errors. If it misclassifies the cutpoint, it indicates so, enabling us to drop misclassified votes from the analysis.

47. Specifically, there were only two votes in our dataset that split the government coalition, and we, therefore, excluded these votes from our analysis. In the twelfth Wahlper, the FDP voted against the CDU/ CSU twice to vote 'yes' on abortion bills with the opposition parties. Note that including these two votes in our analysis would not change our results.

48. Patzelt, 'Chancellor Schröder's Approach to Political and Legislative Leadership'.

49. Sturm, 'Divided Government in Germany'.

50. We did not code as government- or opposition-controlled those seats held by Land coalitions made up of both opposition and governmental parties, or of small regional parties, or universal coalitions of all together (government plus opposition plus small regional parties).

51. For this regression, we exclude Wahlper 9, where FDP was a coalition partner of SPD.

52. Again, for this regression we exclude Wahlper 9, when SPD is a coalition partner of FDP.

53. If policy change is determined solely by the distribution of status quo points and the floor median, then for policy moves to be uniformly leftward (rightward) all status quo points must lie to the right (left) of the chamber median. This might be possible when a rightist government takes over for a leftist government, but it seems like an implausible distribution of status quo points when a rightist or leftist government is in power for a continued amount of time.

54. Gary W. Cox, Mikitaka Masuyama, and Mathew D. McCubbins, 'Agenda Power in the Japanese House of Representatives', Japanese Journal of Political Science, 1(2000), pp.1-22.

55. Cox and McCubbins, Setting the Agenda.

56. König, Thomas, 'Bicameralism and Party Politics in Germany: An Empirical Social Choice Analysis', Political Studies (2001), pp.411-37. 


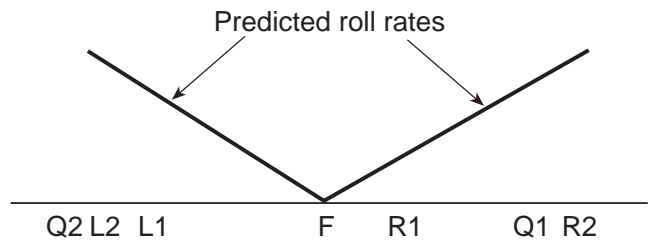

Journal: fGRP - 15:1

Author(s): CHANDLER

Figure No: Fig. 1 


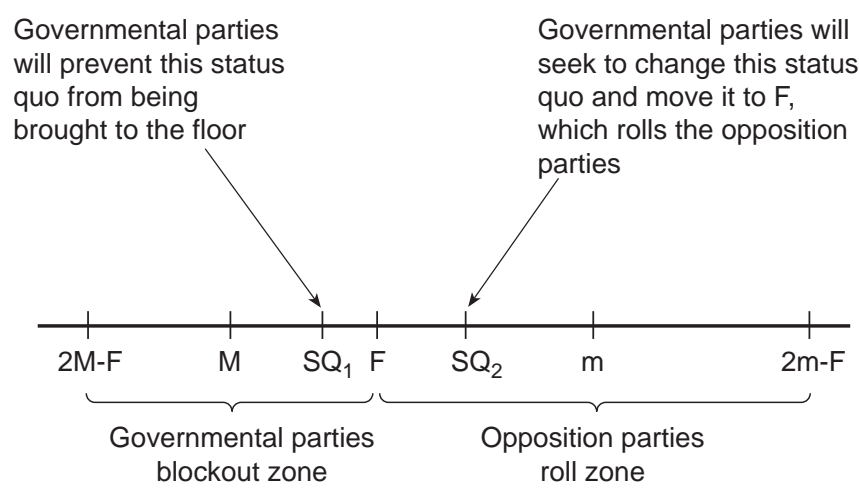

Journal: fGRP - 15:1

Author(s): CHANDLER

Figure No: Fig. 2 


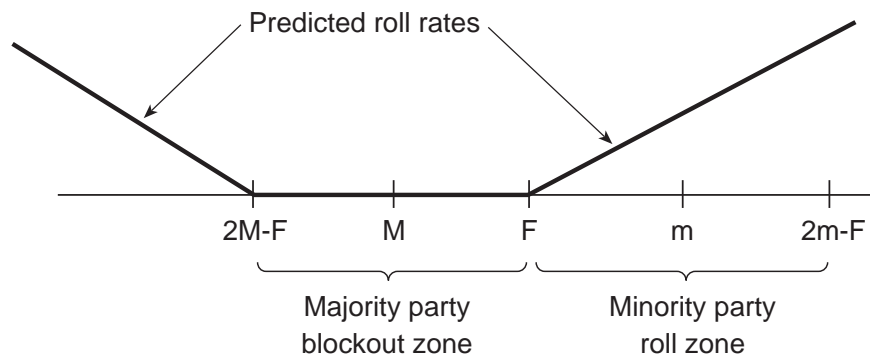

Journal: fGRP - 15:1

Author(s): CHANDLER

Figure No: Fig. 3 


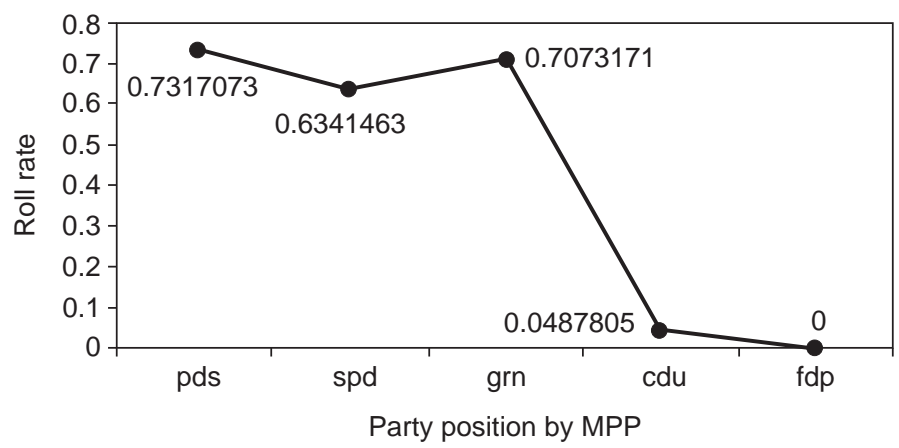

Journal: fGRP - 15:1

Author(s): CHANDLER

Figure No: Fig. 4 


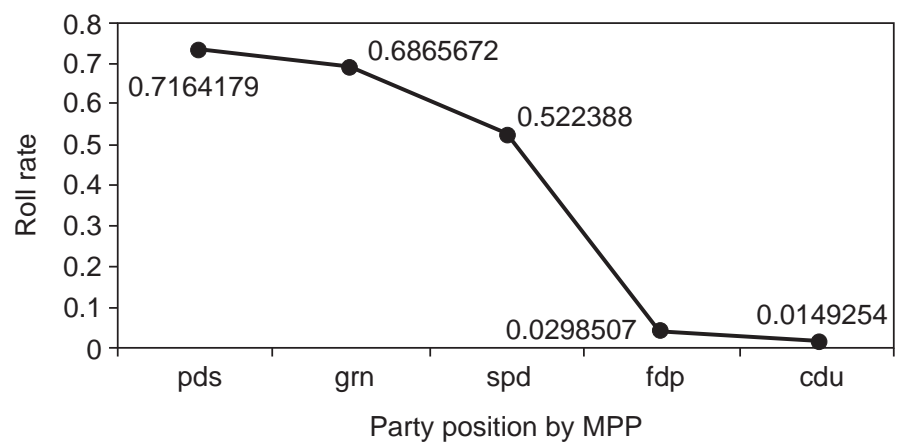

Journal: fGRP - 15:1

Author(s): CHANDLER

Figure No: Fig. 5 


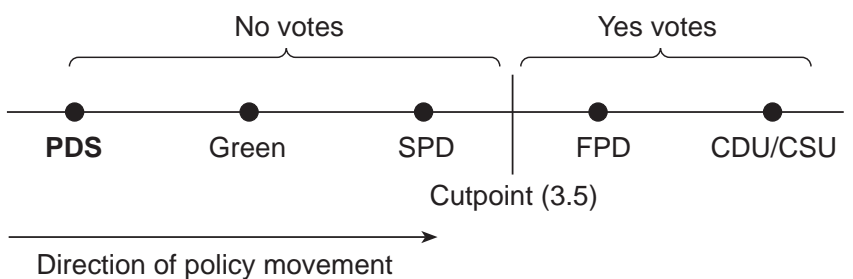

Journal: fGRP - 15:1

Author(s): CHANDLER

Figure No: Fig. 6 